\title{
THE ACTION AT SANDFONTEIN (26 SEPTEMBER 1914)
}

\section{The Background}

On the 21st August, 1914 the first plans for the German South West Africa campaign were discussed at Defence Headquarters, Pretoria, under chairmanship of Genl J. C. Smuts (Minister of Defence).

It was decided, inter alia, to occupy Lüderitzbucht and its surrounding area and to land a task force at Port Nolloth to operate on the Southern border of German South West
Africa in order to resist any possible enemy pressure from that direction. ${ }^{1}$

It was agreed that the A-force under Brig Genl H. T. Lukin, would be transported by ship from Cape Town to Port Nolloth, while the occupation of Lüderitzbucht was entrusted to Col P. S. Beves.

Brig Genl Lukin's force was composed as follows:

The 2nd and 4th (Permanent) Batteries, the

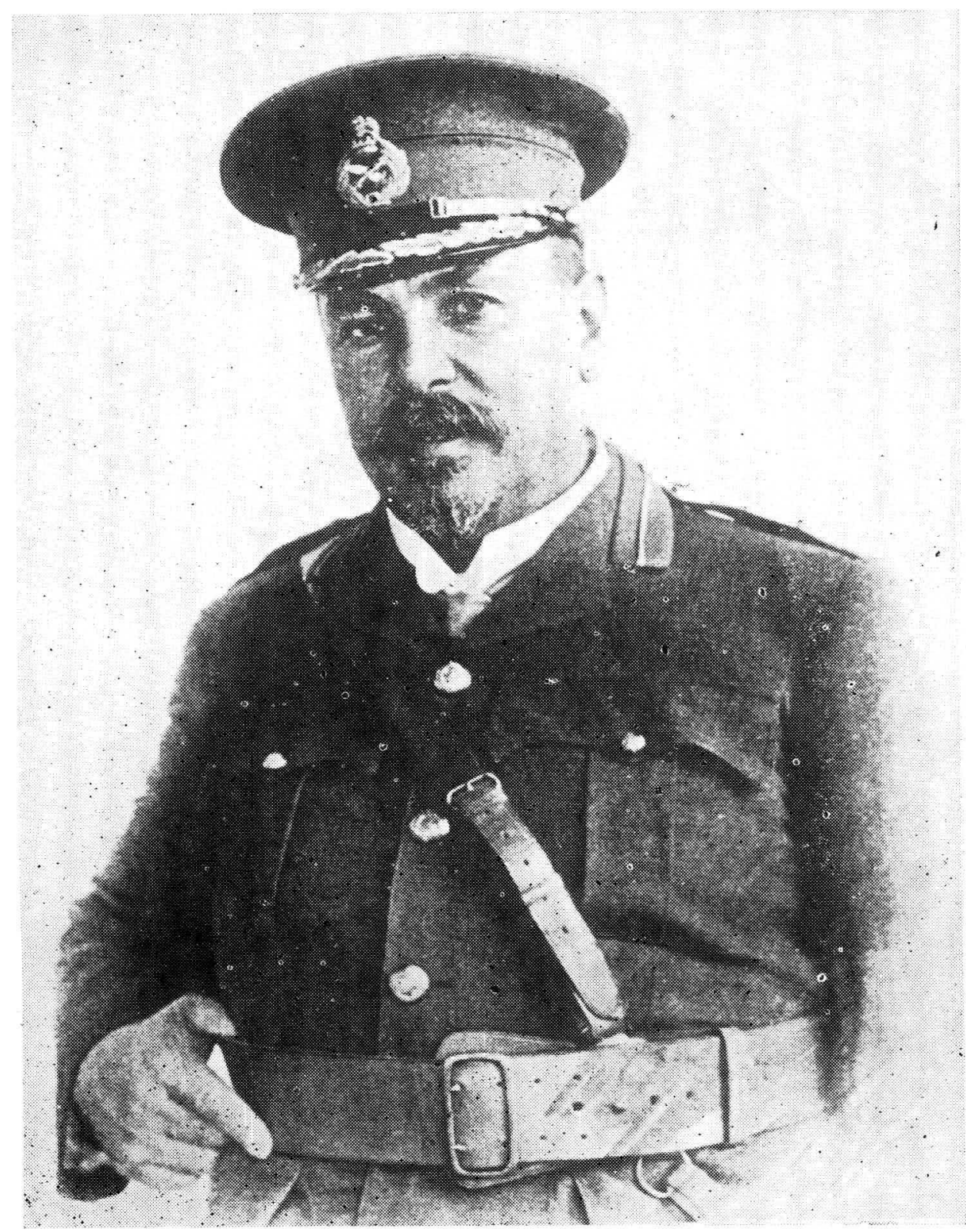

Genl Louis Botha, C-in-C of the Union Forces in German South West Africa.

Photograph: C Doc S 
8̂th (Citizen) Battery (Transvaal Horse Artillery), the 1st, 2nd, 3rd, 4th and 5th Regiments South African Mounted Riflemen (Permanent), the 10th Infantry (Citizen) (Witwatersrand Rifles), one ammunition column, and orie Section Engineers. Total: 2420 all ranks. $^{2}$ On the 31 st August, 1914 Brig Genl Lukin's first transport ship arrived at Port Nolloth and during the night of 16-17th September, the shipping of the A-force was completed.
By 10th September the headquarters of the force, together with the 1st, 4th and 5th regiments, were at Steinkopf.

On the 11 th September patrols were sent to the Orange River and a day later the 4th and 5 th regiments S.A.M.R. under the command of Lt Col F. S. Dawson and Lt Col C. A. L. Berrange respectively, were sent to Raman's Drift and Horn's Drift" with the order to

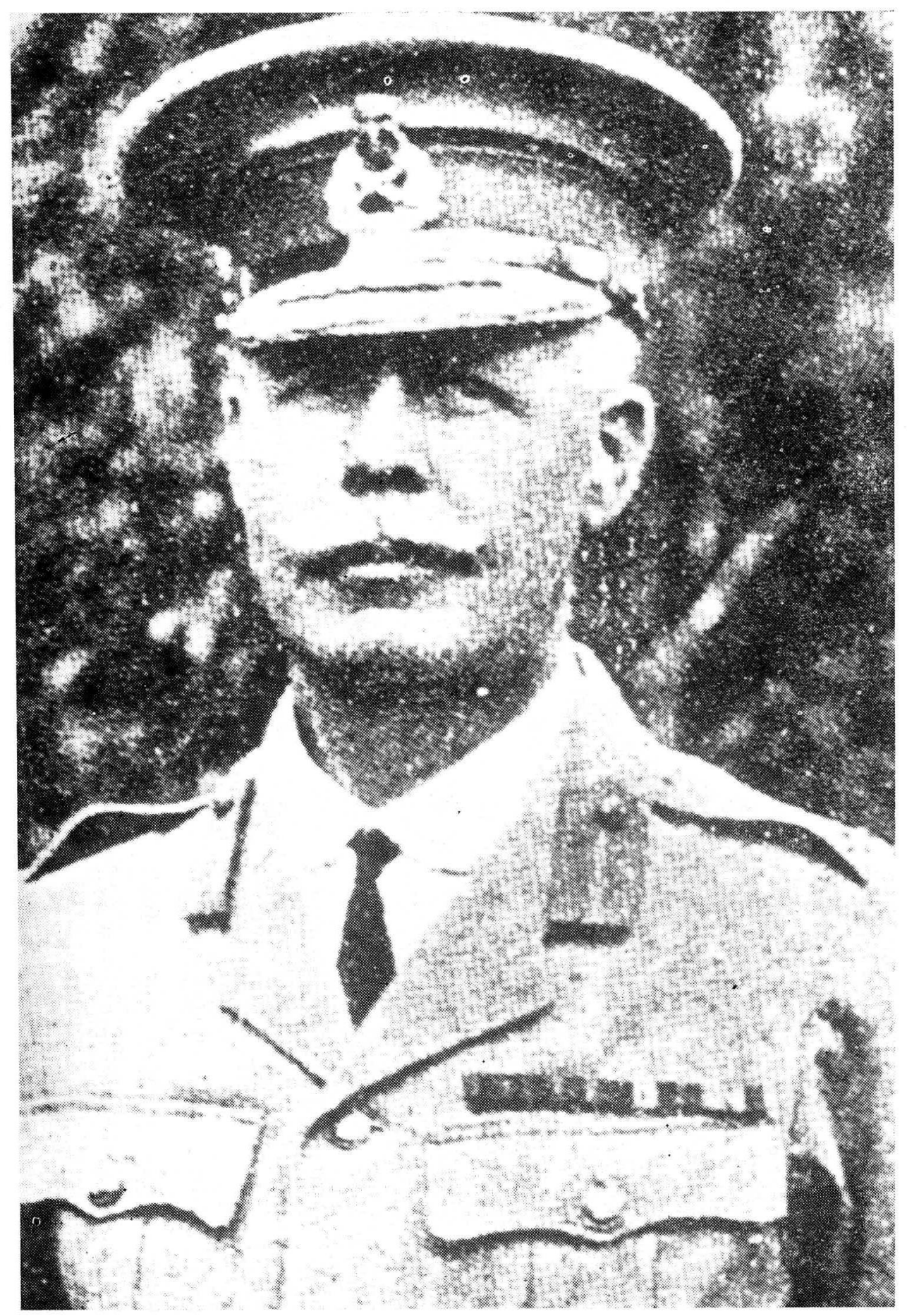

Col P. S. Beves.

Photograph: C Doc S 
occupy the high ground on the opposite side of the river.

On 19th September the wells at Sandfontein, $n$ the direction of Warmbad, were occupied 200 members of 4th and 5th regiment S.A.M.R.

Five days later a squadron of the $1 \mathrm{st}$ regiment S.A.M.R. relieved the troops at Sandfontein. On the same day Brig Genl Lukin with his headquarters and Lt Col R. C. Grant, officer commanding the $1 \mathrm{st}$ regiment, arrived at Raman's Drift.

Telephonic communication was established oetween the headquarters and Sandfontein and the information officer at Sandfontein was enabled to retain contact with Brig Genl Lukin's headquarters in the same way the ocal commanding officers at Raman's Drift and Houm's Drift retained contact with the neadquarters.

At about four o'clock in the afternoon on the 25th September, reports were received from Sandfontein regarding enemy movements east and north east of Houm's Drift. ${ }^{4}$

On the basis of this information, Brig Genl Lukin concluded that a force of about 300 men intended to attack Sandfontein.

$\mathrm{He}$ ordered Lt Col Grant to immediately reinforce the squadron at Sandfontein and on the 26th September, at about 7.25 in the morning, the It col arrived at the scene. ${ }^{5}$

\section{The Battle at Sandfontein}

\section{a. Sources}

In both the official history of the First World War as far as South Africa was concerned and which appeared in 1924, ${ }^{6}$ and the work of Brig Genl J. J. Collyer's, which was published in 1937, short descriptions of the battle at Sandfontein appear. ${ }^{7}$

In the first source it was actually indicated that the German force, that launched the attack, was commanded by the German supreme commander in German South West Africa, Col Von Heydebreck, personally and consisted of two detachments of Maj Von

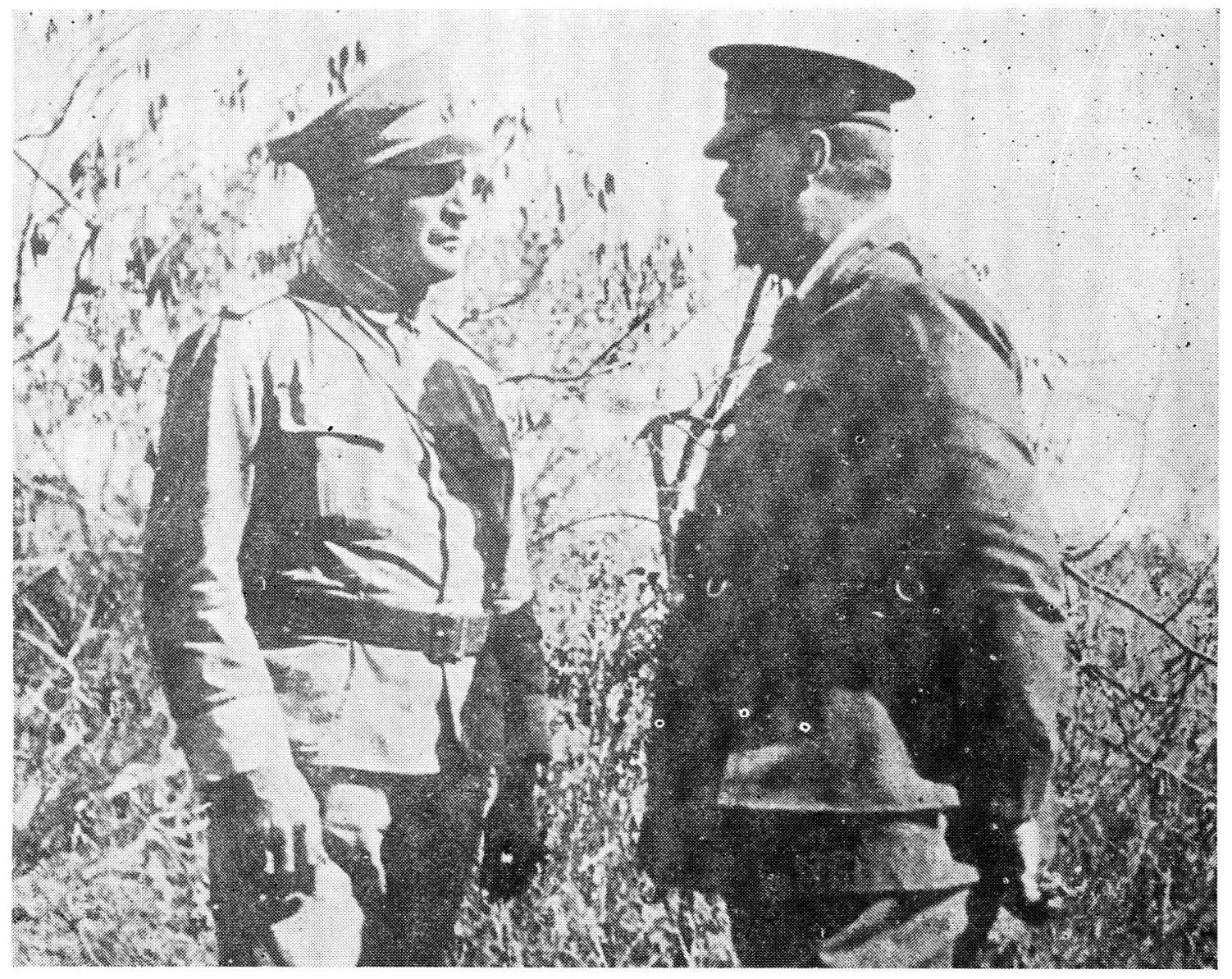

Genl Botha with Col Franke, who succeeded Col von Heydebreck. 
Rappart and Maj Ritter with the detachment of Col Francke in reserve.

The following additional information is supplied in this regard:

Major Von Rappart's column: 3rd Regular Battery (four guns), 2nd Reserve Battery (four guns), 3rd Regular Mounted Company 4th Regular Mounted Company, 5th Regular Mounted Company.

Major Ritter's column: 2nd Regular Battery (four guns), 8th Regular Mounted Company, 4th Reserve Mounted Company.

Major Francke's column: 1st Regular Battery (four guns), 2nd Regular Company, 6th Regular Mounted Company, 1st Reserve Mounted Company. ${ }^{8}$

Notably more comprehensive than the above reports, is a typed copy of a description under the heading The Story of Sandfontein which was found among documents of the S.A.M.R. in the S.A.D.F. Archives. The description runs well over ten pages. Among the same documents was a copy of a typed page under the heading The following are extracts from German accounts of the fight at Sandfontein, September, 26th, 1914.

The contents of both documents are appended in extenso with corrections of several typing errors in the texts. Several sub-headings were provided for easier reading.

\section{3. "The Story of Sandfontein"}

a. The garrisoning of Sandfontein. Reinforcements despatched

Sandfontein, in what was once known as German South West Africa is a group of three wells, situated on the route from Steinkopf, in the Cape Province to Warmbad, in German territory. The road crosses the Orange River at Raman's Drift, the former being the boundary between British and German soil. The distance between Raman's Drift and Warmbad is about forty-five miles and the Sandfontein wells are to be met with about midway between these two points, making their possession to an invading force a necessity and a measure of the utmost importance.

In September 1914, a British column known as the "A" Force under the Command of Brigadier General H. T. Lukin, C.M.O., D.S.O., seized the drifts on the Orange River at Houms, Ramans and Gudaus, and also the Sandfontein Wells, prior to a general advance into the hostile territory.

On September the 25th, the Wells were garrisoned by the second Squadron of the $1 \mathrm{st}$ S.A.M.R. under the Command of Capt E. J. Welby, who had as Troop leaders under him Lieuts C. F. Grahame, A. J. Cowley, W. Owen, R. D. S. Gwatkin, and F. Northway. In addition to these Officers, the detachment included Capt Turner Jones, of the Royal Engineers, who had arrived on the 24th to report on the defensive capabilities of the position, and Capt Genry, ${ }^{9}$ in Command of an Intelligence Staff of ten Europeans and Natives, making a total combatant strength of 120 all ranks.

On the evening of the 25th it was decided to reinforce the Sandfontein detachment by despatching a force from Ramans Drift. This reinforcement, under the Command of Col R. C. Grant (O.C. 1st S.A.M.R.), left the drift at about 6.30 p.m., and was comprised of the following details - One section of the Transvaal Horse Artillery consisting of two 13 pounder quick-firers, under the Command of Lt F. B. Adler; one machine gun section of two guns of the 1 st S.A.M.R., commanded by Lieut W. E. Butler, and three Troops of the 3rd Squadron 1st S.A.M.R. under Capt P. E. Hale ${ }^{10}$ with subaltern Officers in Lieuts D. G. S. Scott, P. B. Clements, and W. G. Austin. The 4th Troop of the Squadron under Lieut G. Allen, was detached at the last moment as escort to the transport, which was intended to follow as soon as the waggons had been loaded with rations for the force.

No rations were issued to the details of the column before leaving the drift, reliance being placed on the transport being capable of keeping close up with the advance. The total strength of this reinforcement was 122, excluding a detachment of the South African Medical Corps, with a field ambulance in the charge of Capt L. A. Holcroft, who accompanied the column on its night march.

Capt Dalton S.A.M.C., with several medical orderlies, was already at Sandfontein. The eventual function of the reinforcements and the detachment at Sandfontein resulted in an available combatant strength of 237 all ranks.
b. A brief description of the Sandfontein region

Before proceeding further, a brief description 
of the country between Ramans drift and Warmbad is needed, in order that the events of the 26th September may be truly appreciated. The greater portion of the region consists of ridges and groops of rugged iron stone kopjes, intersected by narrow sandy defiles. Movement for mounted troops in such an area is restricted to the so-called roads that follow the course of these defiles. The continuity of the rugged country, however, is broken in the vicinity of Sandfontein by a sandy plain, some three miles in width, which commences at the wells and extends away to the West for some considerable distance. The site of the Wells is clearly marked by a conspicious and isolated conical-shaped kopje. This kopje is about 150 feet in height and has two spurs running out from its base a total length of about six hundred yards.

To the South East and North the kopje is overlooked by groups of iron stone ridges, at the ranges varying from six hundred to a thousand yards, those to the South and East being the closest. To the West however, an uninterrupted view of the plain is obtainable. On the plain, and opposite the two spurs of the kopje, there exist numerous stony outcrops, which provided excellent approaches from the North-east and South West, to any force attacking the wells. The latter were situated at the western foot of the kopje, together with two or three dilapidated buildings and a walled enclosure fifty yards by twenty five for kraaling animals. The wells, buildings and enclosure were clearly visible from any point on the plain, which had a gradual slope from west to east.

\section{c. The tactical situation}

The foregoing should suffice to give some idea of Sandfontein and its vicinity, but before proceeding to relate the events of the 26th it is necessary to comment on the tactical situation in order that the true significance of these events may be appreciated.

Access to the Sandfontein plain was possible only by means of the defiles that abutted on it, two of these approaches were provided by the main Raman's Drift Warmbad road, which crosses the plain about three miles west of the wells. A second and shorter road from Warmbad enters the plain from the North East, passes the wells and continues south west to Raman's Drift, running parallel with the main road, which it joins about seven miles from the river. The fifth and only remaining outlet from Sandfontein was via the defile running south to Horn's Drift, fourteen miles distant.

To an enemy operating from Warmbad the isolation and destruction of a force holding Sandfontein was a quite simple matter. By moving down the defiles to the north west and north east of the wells, detachments could be sent south to close the outlet to Horn's Drift and south west to get astride the two roads that led to Raman's Drift. This once accomplished, any force at the wells could be dealt with at leisure; and so it actually occurred.

Having nothing to fear on the south west border, owing to the treachery of Maritz, ${ }^{11}$ the enemy concentrated nearly the whole of his active force, in number about two thousand rifles and three batteries at Warmbad, within twenty miles of Sandfontein.

On the night of the 25th - 26th September, a rapid march south was made to Sandfontein by the two roads already referred to and by dawn the defile to Horn's Drift was seized while another detachment moving down the main road, was in position to get astride the two roads leading to Raman's Drift.

\section{d. The arrival of reinforcements}

Such was the position at sunrise of the 26th, when the reinforcements under Colonel Grant first sighted the Sandfontein kopjes, after an arduous night's march from Ramans Drift. In spite of the fact that the guns and ammunition wagons had their teams supplemented by the addition of extra mules, the pull up from the river through the heavy sand had necessitated a very slow rate of movement, with frequent short halts.

With the exception of an off saddle from one to three o'clock in the morning, men and animals had no rest throughout the night and even at the bivouac, a good proposition of the force was on picket duty while the remainder succeeded in snatching only an hours sleep.

The reinforcements sighted the wells from a distance of three miles and insuspectingly continued the march into the trap that lay ready for them.

There was nothing to indicate that large bodies of hostile troops were hovering in the 
vicinity and that one part of the enemy was now actually in rear of the advancing column. The Advance, rear, and flank guards of the latter were spread well out on all sides, but had met with no opposition, or seen anything to arouse suspicion, with regard to the true state of affairs. The column arrived at the wells at 7.30 a.m. and formed up prior to watering the animals.

\section{e. Patrols sent out. Mounted troops emerge}

It is now necessary to make some mention of the Squadron garrisoning Sandfontein. Pickets had been posted the previous evening in the usual manner, and nothing had occurred during the night to cause any alarm.

It was known that reinforcements were on their way from Ramans Drift which, no doubt, indicated that the situation was well in hands. The event of an unusual nature was detected by the observation post on the summit of the kopje soon after dawn, when the Officer in Command Lieut A. J. Cowley noticed clouds of dust rising among the hills to the north east; some minutes later more dust was seen to the north west, in the direction of the main Warmbad road. On the matter being reported to Capt Welby, a patrol was immediately sent out to the north-east and two others to the north-west to reconnoitre and ascertain the nature of the movements that were indicated.

These patrols were still absent on their mission when the force under Colonel Grant arrived at the wells, whereupon the situation was made known to him by Capt Welby.

It was at this moment, that the telephonic communication with Ramans Drift was found to be interrupted; and as no other means of communication existed, this was a most serious matter.

No sooner had Colonel Grant assumed command than desultory rifle fire was heard to the north-east, and a few minutes later the patrol, under Sergt Spotiswood, was seen retiring before superior numbers of the enemy, whose mounted troops now emerged on to the plain in large numbers, both from the direction of Horn's Drift and Warmbad.

It was at first thought that the enemy were merely attempting some harassing tactics, and the troops under Lieut Gwatkin 2nd Squadron, and Lieut Clemens, 3rd Squadron, were sent out to the assistance of Sergt Spotiswood.

In the meanwhile Colonel Grant, accompanied by his Adjutant Lieut H. S. Wakefield, proceeded to the summit of the kopje; Capts Geary and Turner-Jones were already on this vantage point. Probably fifteen minutes had elapsed by the time the Colonel arrived on the summit, from where it now became clearly evident that the attack from the northeast was more serious than at first thought as enemy mounted troops, in number at least two or three Squadrons, came pouring out from behind the ridge that hid the road to Horn's Drift and where, apparently, they had been in waiting.

\section{f. The enemy's initial intention checked. The defence perimeter reduced}

The remainder of the 2 nd Squadron, comprising the troops under Lieuts Cowley, Owen, and Grahame, were now ordered into position round the base of the main kopje - the latter on the northern face, and the two former on the eastern side. The five from these Units, and of the troops under Lieuts Clements and Gwatkin, very soon had the effect of checking the enemy's initial intention of rushing the position from that side.

After the full strength of the enemy to the north-east had revealed itself, the troops under Lieuts Clements and Gwatkin were withdrawn to man the northern face of the kopje the latter took up a position in a stony outcrop at the foot while the former occupied some schantzes on an under feature.

About the same time a troop under Capt Hale, previously sent out to occupy a high and prominent kopje, overlooking the Ramans Drift Road, was recalled in order to reduce the defence-perimeter. This troop under Lieut Scott, finally took up a position among some sangars at the extremity of the spur that jutted out from the main kopje to the southwest. The remaining troop of the 3rd Squadron, commanded by Lieut Austin, occupied the rest of the ridge, overlooking the wells and between Lieut Scott's troops and the kopje.

Events now occurred in such quick rotation that it is difficult to describe them in their proper sequence. While the enemy were being engaged to the north-east, the unex- 
pected appearance of a body of troops advancing on the wells from the direction of Ramans Drift riveted the attention of all on the south-western face of the kopje.

Seeing that the column under Colonel Grant nad only just traversed this very road, it was hought that, surely, this could not be a nostile force. However, a diversion from quite different quarter - the north-west removed all doubts as to the character of the movement of the south-west.

Lieut Northway, with a patrol of half a dozen men was now observed retiring before an extended line of enemy skirmishers who had entered the p'ain from the main Warmbad Road; a portion of this road could be clearly seen where it encried the p'ain and those who happened to be looking in that direction were now astounded to see line after line of mounted troops advancing at a gallop in rear of the skirmishing line that was driving in Lieut Northway's patrol.

\section{g. Lt Northway's patrol. The Transvaal Horse Artillery (T.H.A.)}

The latter made good his retirement, but not before frequently checking the too bold advance of the enemy riflemen.

Lieut Northway finally dismounted his men in some broken ground about five hunderd yards from the western foot of the main kopje and they sent his led horses in to join the remainder of his Squadron horses, which were still secured to the picket lines in the rear of the main well.

About this time the 3rd patrol of the $2 \mathrm{nd}$ Squadron, under Sergt-Major Barratt, reappeared from the south-west, retiring in extended order.

The enemy were showing themselves on all sides in such a bewildering manner that this party were credited with hostile intentions and fired on in error, fortunately without sustaining any casualties, and patrol safely made its way into the main position.

No mention has yet been made of the section of the Transvaal Horse Artillery. On the appearance of the strange force on the Ramans Drifts road, the guns were unlimbered between the walled enclosure and the main well and between the latter and the kopje; the mule teams were grouped against the north-east wall of the enclosure.
Up to now no more than half an hour had elapsed since the arrival of Colonel Grant's small column and the time was now 8 o'clock.

The times quoted for the various events must be taken as merely approximate, and it is quite possible that there may be discrepancies of as much as half an hour one way or the other.

Before proceeding to describe the main engagement which may be said to have commenced at 8 a.m., by the discharge of the first two rounds from the artillery of ours, it is perhaps necessary to review the tactical situation as it now stood.

\section{h. The tactical situation at $\mathbf{0 8 . 0 0}$ hours. No offensive movement}

It will be noticed that the whole of the force at the wells was now disposed round the Sandfontein kopje in such a manner as to deny enemy access to it, thereby ensuring the retention of the valuable water that lay at its feet.

This disposition may give cause for the remark as to why no offensive move was attempted. Against the first body of the enemy that appeared to the north-east an offensive movement was commenced and would have continued except for the appearance of the enemy on the exposed flank, and in the rear of the wells. The position was being attacked simultaneously from four widely different points by hostile bodies, any one of which was superior in numbers to the detachment at the wells.

An offensive movement againt either of these bodies would have meant partial or total withdrawal from the water - a step of no mean importance when it is remembered that the next nearest water was twenty miles away.

An equitable adjustment of the tactical situation could only have been brought about two hours earlier by getting astride the main Warmbad road and delaying the enemy in the defile to the north west, thus ensuring the safe retirement of the detachment guarding the wells.

At 8 o'clock it might have been possible by leaving the water, abandoning the guns, transport and ambulance, for the two hundred 
riflemen to make a running fight of it to the west, in the faint hope of evading destruction. At 8 o'clock, as matters now stood, there is no doubt whatever that the situation of the force was tactically quite hopeless and no amount of readjustment of the meagre members available could have brought about an improvement.

\section{i. The artillery duel starts}

After this digression the events that commenced at 8 a.m. may now be related. The rapidly advancing force to the south-west was still some four thousand yards distant, when it was decided that this must be the enemy, and the order was given for the artillery to open fire. The gunners were not long in complying and the simultaneous discharge of the two quick firers echoed again and among the surrounding hills followed a few movements by the fainter sound of the exploding shrapnel. Unfortunately the range had been sadly underestimated, as the shrapnel was seen to burst quite six hundred yards short of the target; however, the next few rounds very soon found the spot, and the white smoke of shells could be seen mingling with a dust raised by the enemy, who at the first discharge of our guns turned sharply to the right, and opening well out, shortly gained the shelter afforded by the lower slope of the range of hills to the south of Sandfontein. Any doubts as to whether this was a hostile force now dispelled as, once clear of the dust, the dissimilarity in dress could be made out in aid of binoculars.

In the meanwhile the ${ }^{12}$ had loosed of about ten rounds when quite a new event changed the whole complexion of affairs. From among the hills to the north-east there suddenly came to the ears of all the faint discharge of guns, and the next moment a beautifully timed shrapnel exploded over a building in rear of our guns; the gun teams were right in the line of burst and a native driver and a mule were seen to fall to the ground.

The group of animals were hastily transferred to the other end of the enclosure, while the muzzles of both our guns were swung smartly round to meet this unexpected attack.

Quite a stream of shells, both precussion and time fuse, were now commencing to fall in and around the enclosure, close to which our guns had come into action, from which it could be inferred that at least a four-gun battery was being utilised by the enemy. This battery came into action at the range of four thousand yards, among the hills at the mouth of the defile to the north-east, and occupied what is now as a semi-covered position, i.e. though the guns were invisible, the dust and smoke caused by each discharge could be easily detected.

When our guns first opened fire Lieut Adler had made his observation post on the low ridge overlooking the guns, but he was now compelled to descent to a spot near the enclosure, as the northern slopes of the Sandfontein kopje intervened between the observation post and the hostile artillery position.

Our two guns were not long in opening fire on the new target, and on this occasion no mistake was made about the range, as the first shrapnel were seen to burst exactly over the ridge concealing the hostile battery, which, by now, had found the range of our guns to a nicety dropping their shells with the greatest precision all round their target. A number of time shrapnel were also directed at the summit of the kopje, driving those there under cover; the enemy were evidently under the impression that this point was being utilised by our artillery as an observation post.

Though outnumbered the T.H.A. guns more than held their own at one period by the accuracy of their fire, brought about a temporary cessation of the hostile fire.

While this artillery duel was in progress events in the other portions of the position deserve extension.

\section{j. Events elsewhere in the position}

Immediately the enemy's riflemen commenced to develope their initial attack from the northeast, the machine gun section, under Lieut Butler, was ordered into a position on a projection knoll to the south-east of the main kopje; the one gun under Sergt Pizzey came into action almost at once against bodies of hostile riflemen, who endeavoured to cross an open space about one thousand yards distant, in order to establish themselves amongst certain rocky outcrops which provided an easy approach for an attack on the 
main kopje. The fire from this gun, together with the rifle fire of the troops on that side op the position, soon brought this too daring a movement to a standstill, and the majority of the enemy riflemen returned from whence they had emerged.

In the meanwhile the remaining guns under Lieut Butler himself, were posted in a sangar from where the plain to the west and Ramans Drift road could be commanded.

The hostile artillery had by now opened fire, and it was thought advisable to keep the machine gun pack animals and horses on the southern slope of the kopje, where they would be immune from the shell fire directed on the position from the north-east. The majority of these animals were held by native horse holders, and stood a compact group when, without warning, an enemy machine gun from a position about eight hundred yards away on the ridge to the east, applied a sharp burst of fire on what must have been a splendid target.

The effect was immediately disastrous as the natives abandoned the animals, and with a head long rush sought cover on the western face of the kopje, where they remained concealed during the rest of the day. Several of them must have been hit, as a shower of bullets could be seen striking the rocks at their feet, and a number were observed to fall in their mad fight, but picked themselves up again and succeeded in gaining their objective.

The unfortunate group of animals were left in a parlous condition, but not for long, for kicking left and right, they scattered in all directions, and the majority fell victims to the murderous fire. Some few succeeded in gaining the plain at the foot of the kopje, where for sometime, they continued to graze between the opposing firing lines undisturbed by the fearful medley of sounds produced by the artillery, machine gun, and rifle fire of both sides.

\section{k. Lt Owen wounded. Control of fire most difficult}

The hostile machine gun to the east, which was cleverly concealed, now directed a searching fire all over the south-eastern slopes of the kopje, and also applied bursts of fire to the summit.
It was one of these bursts that resulted in Lieut Owen being dangerously wounded in the head. It was subsequently found that this Officer had permanently lost the sight of both eyes.

The machine gun under Sergt Pizzey, endeavoured to cope with the hostile fire but with little success. Our guns were equipped with a pattern of tripod which made concealment impossible and the enemy very soon located Sgt Pizzey's gun and applied a burst of fire with such effect that even the gun was struck by a showring of bullets, causing the detachment to upset the weapon in order to prevent themselves and the gun from being completely destroyed. This must have occurred about 9 o'clock or an hour after the action had been in progress.

The continuous hostile machine gun fire from the east seems to indicate that at least two guns were in action at this period. The enemy machine guns were extremely well handled, and their fire was one of the greatest factors in bringing about, so early in the day, a situation that rapidly became more hopeless as the engagement progressed. The storm of bullets made any movement in the open impossible, and the control of fire by Unit commanders was rendered most difficult.

The cover available on the kopje was very crude, consisting of a number of scattered and broken down sangars, the walls of which were barely two feet high, and which were composed of stones loosely piled up, leaving the many crevices, and consequently far from bullet proof.

\section{Second enemy battery brought into action}

Mention has already been made of the enemy's appearance from the defile leading onto the plain from the north-west and of the driving in of the patrol under Lieut Northway. On the plain, opposite the defile, there existed a low and conspicious stony ridge and from here the enemy provided another bolt from the blue, by bringing into action a second battery about 8.30 a.m.

The situation was critical enough as it was, but the arrival of a string of shells from this direction made the western and north western face of the position a death trap, not only for two guns, but also for the three hundred horses and mules that were collected at the 
foot of the kopje there was not a vestige of cover except provided by a low wall of the enclosure, and a single small building which could not give security to more than a dozen men.

Up to the present the animals had been sheltered from the hostile battery to the north-east by the northern slope of the Sandfontein kopje, but now the position of the horses and horse holders was indeed precarious. However, for the moment their destruction was deferred, while the hostile artillery devoted all their attention to silencing the two Transvaal Horse Artillery guns.

Immediately fire was opened from the northwest the one gun, under battery Sergt Major Harris was turned on to the new target; the two guns were now almost trail to trail, firing at right angles to each other and furnished with the stupendous task of engaging the battery each - themselves in a position that was perfectly open.

The range to this second hostile battery was somewhere about three thousand yards, and the enemy guns were clearly visible, with the result that the very first rounds from our gun made things so uncomfortable for then that their weapon had to be withdrawn behind the ridge in order to resort to the indirect and more orthodox method of applying their fire. For some considerable time the shooting of this battery was extremely indifferent, many of their shells pitching well over our guns on the ridge behind while others fell far short of the mark; but gradually their fire became more accurate, until the two cones of fire, the one from the north-east and the other from the north-west completely enveloped our gun position in a shower of bullets and exploding precussion shrapnel.

The wall of the enclosure, which was about five feet in height, and over which the one gun was firing, gave some little protection, otherwise the two guns were exposed to a most deadly enfilade fire, against which the steel shields of the weapons were of very little value.

\section{m. Casualties. The S.A.M.C. in action}

The first casualties amongst the gunners occurred about this time, with the result that the services of the medical staff were now requisitioned. Headed by Capts Holcroft and
Dalton, the S.A.M.C. orderlies doubled across the shrapnel swept area behind the guns, and succeeded in getting the wounded men under cover of the wall of enclosure, where first aid was promptly applied, under conditions which could not be equalled for their severity. The first shells from the north-west again brought the gun teams under fire, but after some delay, and the personal direction of Lieut Adler, they were at last got away to where the remainder of the animals were grouped at the foot of the kopje; not before several of the drivers and animals had been hit.

\section{n. Events on the Raman's Drift side of the position}

Attention must be withdrawn from the guns in order to describe the events in the southwest, or Raman Drift side, of the position. The initial advance had been checked by our gun fire at the opening of the engagement, but only temporarily. For gaining the shelter of the hills to the south, parties of the enemy presently emerged from round the base of it in skirmishing order at a distance of about five hundred yards. Numerous trees and bushes dotted the plain on this side, while nearest still various stony outcrops provided the hostile riflemen with an excellent approach to within three hundred yards of their objective, collective fire was at once opened on these skirmishers by the troops under Lieut Scott and Austin, with some effect as the enemy appeared to make slow progress, and then only after the first line had been reinforced by several succeeding lines of riflemen.

The machine gun under Lieut Butler also succeeded in checking the advance from this direction by applying short bursts of fire whenever a suitable target was available: these were extremely near as the enemy conducted its advance in the approved modern style of widely extended lines of riflemen who only showed themselves singly for a few moments at the time, making it very difficult to locate any number together in one spot.

Between 10 a.m. and 10.30 a.m. a party of the enemy, numbering about fifty, suddenly appeared over a nek in the hills to the south, and with their rifles slung over their shoulders calmly commenced to descend a rough path 
leading down to a water course that ran along the foot of these hills. The range was only one thousand two hundred yards, and the target a splendid one for collective rifle fire. The opportunity was immediately taken advantage of, and a stream of bullets very soon fell amongst the exposed Germans causing at least half a dozen casualties as quite that number were observed to fall. A portion of this force succeeded in gaining the shelter of the water course, dragging their dead and wounded with them, while the rest hastily disappeared behind a knoll.

Out machine gun and rifle fire at these longer ranges brought the hostile rifle attack to a complete stand still for a period of about three hours, and the forward was only recommenced at about noon, under machine gun and artillery covering fire.

Meanwhile, the artillery duel continued without cessation; the hostile gunners had by now gauged the position of our guns to a nicety, and directed such a deluge of she.ls on to the two guns that one wonciered how they could remain in action as long as they did.

\section{o. A climax reached by $\mathbf{1 0 . 3 0}$ hours}

However, by 10.30 a.m. matters suddenly reached a climax by the enemy scoring a direci hit on the gun under Sergt-Major Harris who was killed on the spot while the remainder of the gun crew all disabled. By this time the detachment of the other gun had also been greatly reduced by casualties; nevertheless those remaining continued to work their gun with the greatest vigour.

After some minutes the gun had been temporarily silenced reopened fire, being handled by two of the spare members.

By now the ammunition was nearly all expended, and the greatest difficulty of all was to get up to the guns the few rounds remaining in the wagons, which were somewhat in the rear. The guns continued in action for another ten of fifteen minutes, the gunners sustaining a number of further casualties, which at last brought this unequal contest to an end. The guns were now abandoned, the remnant of their detachments being withdrawn to the main kopje, where they continued to assist the defence with their rifles.

\section{p. Lt Adler retires}

Before retiring Lieut Adler inflicted as much damage to the abandoned guns as was possible under the circumstances, in order to render them useless to the enemy.

The two guns had been in action for three hours in an open position against four time their number, and were only silenced after the detachment had sustained casuaities to the extend of fifty percent. Apart from the great volume of artillery fire, the coming into action of an enemy machine gun on the Rarinans Drift road made the continuation of fire by our guns quite out of the question, as it would have resulted in the annihilation of the gunners. If properly constructed gunp.ts had been availab'e the guns would have probably remained in action for some time longer. In any event the guns were abandoned none too soon as th? artillery Officer had barely left the guns when the ground all round commenced to be peppered with a stream of bullets.

\section{q. Position of S.A.M.C. becomes untenable}

The appearance of this machine gun to the south-west made the position of the South African Medical Corps with the.r wounded against the east wall of the enclosure, quite untenable, and taking the wounded with them they sought shelter inside the enclosure by means of the gate, which was close by.

How the Medical Staff escaped the shell fire remains mystery, as they were only a few yards from the guns while the artillery was in progress. Once inside the enclosure the S.A.M.C. was compelled to remain there throughout the rest of the day, as movement between the enclosure and the kopje was rendered impracticable by hostile machine gun fire. The open space at the foot of the kopje was now deserted and all that caught the eye were the abandoned guns and ammunition wagons.

Now that our guns were silenced the hostile battery to the north-east ceased firing, while the other, to the north-west, directed its attention to the lines of animals which were grouped at the base of the kopje. The horse holders were soon compelled to leave their animals and seek the scanty cover available on the kopje itself but this was not 
accomplished before several men had been killed and wounded.

\section{r. Animals killed by enemy's fire}

About two hours shell fire sufficed for the destruction of the majority of the horses and mules, many of them being blown to pieces by direct hits from the percussion shrapnels, while the time shrapnel accounted for three or four at a time, until the locality was a veritable shambles.

At the end of the day there must have been at least two hundred dead animals lying within an area no more than fifty square yards. No cover could have been found for the animals on any other part of the position, as every portion was now being swept by machine gun fire, which would have made their destruction just as speedy and certain. It may be said that by noon the defenders of the kopje were rendered quite immobile by the total destruction of their mounts. The most remarkable feature of this bombardment was the indifference in which the victims awaited their fate; the majority huddled even closer together, while the few that were loose made no effort to get away, but rather preferred to join those secured to the picket lines. This wholesale slaughter was certainly the most heart rending incident of the day.

\section{s. Renewed enemy artillery and machine-gun attack}

About 11 a.m. hostile artillery were observed moving across the plain to the south-west, evidently having been detached from the body of the enemy to the north-west. Crossing the Ramans Drift road two guns quickly unlimbered on the plain at the foot of the hills to the south of Sandfontein, and about two thousand five hundred yards from the kopje. Fire was commenced shortly after and continued unceasingly for two hours; the shells, both percussed and time fuse, were directed on to the lower slopes of the main kopje and the spur that lay at its foot.

By noon the enemy machine gun had established itself among the stony outcrops along the Ramans Drift road, where it was cleverly concealed and difficult to locate. The continious covering fire of this gun, in conjunction with that of the artillery, allowed the rifle attack to be pushed with greater vigour, and by one o'clock enemy skirmishers had succeeded in getting within six hundred yards of the kopje, whence their rifle fire was added to that of the machine guns and artillery.

The machine gun under Lieut Butler endeavoured to suppress this fire, but the approximate position of his gun being located by the enemy, such a storm of shrapnel and machine gun fire was poured on to the locality that our gun was silenced.

Our riflemen were now compelled to resort to snap shooting between the burst of machine gun fire and the slight lull that prevailed after the arrival of each batch of shells. The sandy plain was very suitable for the observation of fire, and in many cases, by working in pairs, our riflemen did some admirable shooting, which time and again held up the advance of the enemy riflemen all round the position. In order to secure cover in the schantzes our men were compelled to lie at full length; even a sitting position was impracticable. Under these conditions apart from the severe shells and machine gun-fire, the best rifle shooting could not be expected, and yet the enemy attacking lines were repeatedly held up by our musketry.

The rifle attack from the north-east and east still continued under the cover of machine gun-fire, but the enemy made little progress against the rifle fire of the troops on the side of the kopje. Curiously enough the enemy made no attempt to shell the side of the kopje though the battery of the north-east was well posted for such a purpose.

From this it may be inferred that the attack from the north-east was more of a holding nature and that the main attack was the one from the south-west, which aimed at gaining the position at the wells.

\section{t. The situation at $\mathbf{1 3 . 0 0}$ hours}

By one p.m. the enemy must have expended a large amount of gun ammunition, so that when the two guns to the south-west suddenly ceased firing the hope arose that it was due to a shortage of shell, but such was not the case.

The defenders had only previously experienced a keen disappointment in hearing distant machine gun fire to the south, which indicated that a relieving force was endeavouring to gain touch with the besieged; the sound of firing, however, grew fainter and fainter show- 
ing that the attempt at relief had failed and that the advancing force had been repulsed and driven back by the enemy.

t was at noon that Colonel Grant was wounded by machine gun fire from the south, and the command developed upon Captain Nelby; late in the afternoon Colonel Grant assumed command.

$t$ was in the early part of the afternoon that cieut Northway, finding himself in danger of peing cut off from the main kopje, endeavourad to regain it with three men of his patrol hey were all killed by machine gun fire; the emainder of the patrol, being pinned to their ground, were captured by the advance of enemy skirmishers.

\section{A temporary lull in the fighting}

Between 1 p.m. and 2 p.m. a distinct lull cccurred in the fighting, though desultory rifle ire from both sides continued during this seriod. The enemy utilised the hour for makng new disposition and for enjoying their nidday meal.

There was no such relief for the besieged, nany of whom had experienced a sleepless hight, and were now feeling the pangs of inger and thirst. The action had commenced with such suddenness that many had no time o refill their water bottles.

The heat of the sun, reflected off the iron tone rocks, was something terrific and, as here was no shade, it made the situation almost unbearable.

During this interval the two guns to the south-west were moved into the centre of he plain, almost due west of the Sandfontein copje. The obpect of this manoevre became ipparent later in the afternoon, when the anemy gunners had the setting sun behind hem while their target was in the very best ight. The position of these guns was about wo thousand five hundred yards from Sandontein.

\section{The bombardment recommenced}

At 2 p.m. the bombardment was recomnenced by the guns to the west and those o the north-west. The very crude and inonspicious character of the sangars now roved the salvation of many on the defendng side, as the enemy artillery were unable o detect the position of the various troops compelling him systematically to search the whole of the kopje on this side, from end and from top to bottom, in the hope of demolishing the sangars that were known to be there. An aeroplane would have been of the utmost value to the enemy at this stage. The shelling was continued unceasingly throughout the afternoon and though little material damage was caused, excellent covering fire was provided for the rifle attacks.

The shell arrived in series of four and sometimes six, first of the percussion variety, which explode on contact, and then time shrapnel.

It is estimated that the enemy must have thrown between two and three thousand shells on to the position during the course of the day.

The result, as far as casualties were concerned were extremely meagre, the enemy only scoring two direct on the sangars, thereby killing two men outright.

\section{w. The situation becomes critical for defend- ers}

By 5 p.m. very critical for the besieged under cover of the incessant artillery and machine gun fire, the enemy succeeded in forming thick firing lines within three hundred yards of the kopje, both to the north-east and south-west.

By this time complete superiority of fire had been gained by the Germans, further progress was possible only by means of an assault with the bayonet, this measure they seemed to be very averse to undertaking, relying more on their artillery, machine gun, and rifle fire to bring the contest to a conclusion. All kinds of fire at this period were very intense. About 5.30 p.m. the enemy advanced a section of mountain guns to within one thousand two hundred yards to the northern face of the kopje, and in conjunction with the other guns, a most terrific and concentrated bombardment of the summit of the kopje was suddenly commenced.

The ten hours engagement thus entered on its last phase. The enemy now employed high explosion shells, and to those on the lower slopes of the kopje the summit appeared like an active volcano. The shells burst in salvoes of four at a time, emitting flames and smoke of various colours in such quantities 
that portions of the summit were quite invisible to those below. Rocks of enormous size were flung in all directions and dozens of boulders were sent rolling down the slopes, placing the defenders at the base of the kopje in every danger of being crushed to death.

The effect of the high explosive shells on the summit of the kopje was so great that in a short space of time the appearance of the kopje was quite altered. There is little doubt that this bombardment had continued for any length of period, most of the summit would have been removed piece meal. The bombardment had only continued for about a quarter of an hour but with the result that, in addition to Colonel Grant, who was already wounded, the members of his Staff, composed of Captains Turner-Jones and Geary and Lieut Wakefield were also wounded.

Meanwhile the enemies machine gun and rifle fire was redoubled and though every effort was made to reply it, the situation was now recognised to be perfectly hopeless. Hemmed in on all sides, without food or water with no hope of being relieved, no good purpose would seem to be served by continuing a contest in which the defending side had held on to an untenable position for ten hours against an indefinitely superior force of men and guns.

\section{$x$. Action brought to a close}

Shortly before 6 p.m. the rising of the white flag on the summit of the kopje brought the action to a close in favour of the enemy. There was little or no demonstration on the part of the enemy. The last rays of the setting sun showed both sides making one dash for the well at the foot of the kopje, where British and Germans mingled as if never a shot had been fired.

The captors gave every consideration to the prisoners that was possible under the circumstances, an exceilent example being set by the German Leader, Colonel von Heyde- brecht, who congratulated Colonel Grant or his gallant defence.

At 8 o'clock that night the prisoners were marched off into the interior under a strons escort. The rank and file walked, but the captured officers were provided with horses Captains Holcroit and Dalton assisted by Lieutenant Cowley, remained to attend to the wounded.

\section{y. Casualties}

The British ${ }^{13}$ casualties, including those with minor wounds, amounted to sixty seven o twenty two percent of the force; sixteer were killed or died of wounds. The Germans published a casualty list of sixty, including fourteen killed, among whom was Major vor Rappart, one of the best known Germar leaders.

Tho enemy forces that took part in the action amounted to ten guns, four mach:ne guns and 1500 rifles.

The dead were buried the following day, the British being accorded the same honours as the Germans. ${ }^{14}$

NOTES:

1. Collycr, J. J.: The Campaign in German South West Afric 1914-1915. Pretoria, 1937, p. 27 et seq

2. Each S.A.M.R. regiment consisted of three field squadron which consisted of 100 mounted riflemen each. Collyer, op cii., p. 30 .

3. In the later descriptions the spelling is Ramans Drift an Houms Drift and in one instance, incorrectly Horns Drif

4. Collyer, cp. cit., p. 37.

5. Ibid., p. 40.

6. The Union of South Africa and the Great War 1914-191 official H story. Pretoria, 1924, pp. 14-15.

7. Collyer, op. cit., pp. 40-43 (with map opposite to p. 40).

8. The Union of South Africa..., op. cit., p. 14.

9. Capt Genry = Capt Geary.

10. Capt. P. E. Hale = Capt P. E. Hole.

11. See Collyer, J. J., op. cit., pp. 32-34 i.r.o. the militar situation.

12. Word missing after the.

13. Mention was erroneously made here as welf as in th beginning of the report, of British troops. Only a sma number of British troops were added to the Union troop who were involved in the battle.

14. According to The Union of Soutin Arrica and the Great Wa 1914-1918, p. 15, the casualties were as follows: Lt Co Grant's casualties were 16 killed and 51 wounded, whil the German losses were 23 killed. 


\section{jerman Mîlítary Reportíng}

\section{and Comments}

The following translated extracts of German reports on the action at Sandfontein were found with the above descriptions.

The first reads as follws:

$$
\begin{aligned}
& \text { Windhuk, } \\
& 28-9-1914 \\
& 1 \text { p.m. }
\end{aligned}
$$

With reference to the battle of Sandfontein, the Commander of the Protectorate troops still announces the following:

At Sandfontein active English Union troops of 3 squadrons with Machine Guns, section of Field Artillery had entrenched themselves, but were attacked eariy on the 26th from North West, South East, and North East at the same time. They fought bravely and shot well. Three supporting troops, two from Ramans Drift and one from Gaidib were repulsed. At 5 o'clock in the afternoon the enemy showed white flags after our Mountain Artillery had pushed forward into the Rifle line. Un-wounded prisoners, 8 Officers, 20 N.C.O.'s and 160 Riflemen, 44 natives, Guns and Machine Guns are being transferred to Windhuk. Bloody losses of the opposers rather high. The list of casualties is being compiled as soon as possible. The dead buried with Military honours at Sandfontein.

The other extract reads as follows:

On Sunday early, shortly before the church bells were rung news was received of a 12 hours fight close to Sandfontein some 25 kilometers from Ramans Drift on the road to Warmbad, and also stated that the British left in our hands, 1 Colonel, 14 Officers, 200 N.C.O.'s and Riflemen, furthermore, 2 modern guns, Machine Guns, 9 waggons and Vehicles of all description and riding and draught animals. About this the first of the larger fights we will give news later.
This surprise was brilliantly carried out, and notwithstanding the defence and good shooting and also 4 relief columns who were undertaken from the sides of Ramans Drift and Gaidib (16 kilometers West of Ramans Drift situated on the West of the Orange River) it ended with a total collapse of the English division, when also the much beloved Major von Rappart who already had fought with great distinction in the late war, and had been wounded over and over again, found a most beautiful death, that is, a death on the field of honour, and also many sacrifices have also to be mentioned, still this victory, is in many a way of the utmost importance, following material results which have been bought with slight losses to our troops owing to the wonderful leading of the fallen Major von Rappart.

The people in Windhuk will see within the next few days the captured guns and also arms and prisoners of the 1st Active British Troops.

This speaks more than numbers. And then further the moral result we know, that in consequence of a real better leadership and knowledge of the country, and Military training, the victory came to our arms with very small losses. The confidence in leaders is also not least valuable factor from Military point of view, that the unbending desire for victory and the knowledge, that we have been treated in a most shameful and disgraceful manner, and that our enemy fights with the meanest and most despicable arms and that this enemy is not even ashamed to take exception to our wives and children when they fall in his hands.

What the sequence of this to our troops in a moral war. It is though an extraordinary 
measure for those farmers who are seeking for freedom inside and outside the Protectorate.

That they know they can depend on us, and that we ourselves, here in the colony, were strong enough to defend ourselves against the English power.

May come what will, we Germans are standing like God in this belief and rightious sake.
We go with courage and faith to the defence of our country which has already drank streams of German blood.

This faith, however, had a real support through the act of the fallen Major von Rappard and his troops.

This is the biggest win of the fight at Sandfontein on the 26th of September, 1914. 